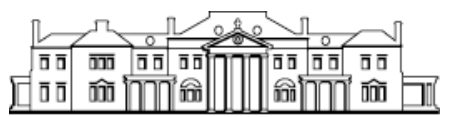

Levy Economics o

Institute

of Bard College

Working Paper No. 869

\title{
Have We Been Here Before? Phases of Financialization within the 20th Century in the United States
}

by

\author{
Apostolos Fasianos* \\ University of Limerick \\ Diego Guevara \\ University of La Sabana \\ Christos Pierros \\ University of Athens
}

June 2016

* Corresponding author: apostolos.fasianos@ul.ie.

The Levy Economics Institute Working Paper Collection presents research in progress by Levy Institute scholars and conference participants. The purpose of the series is to disseminate ideas to and elicit comments from academics and professionals.

Levy Economics Institute of Bard College, founded in 1986, is a nonprofit, nonpartisan, independently funded research organization devoted to public service. Through scholarship and economic research it generates viable, effective public policy responses to important economic problems that profoundly affect the quality of life in the United States and abroad.

Levy Economics Institute P.O. Box 5000

Annandale-on-Hudson, NY 12504-5000

http://www.levyinstitute.org

Copyright (C) Levy Economics Institute 2016 All rights reserved 


\section{ABSTRACT}

This paper explores from a historical perspective the process of financialization over the course of the 20th century. We identify four phases of financialization: the first, from the 1900s to 1933 (early financialization); the second, from 1933 to 1940 (transitory phase); the third, between 1945 and 1973 (definancialization); and the fourth period begins in the early 1970s and leads to the Great Recession (complex financialization). Our findings indicate that the main features of the current phase of financialization were already in place in the first period. We closely examine institutions within these distinct financial regimes and focus on the relative size of the financial sector, the respective regulation regime of each period, and the intensity of the shareholder value orientation, as well as the level of financial innovations implemented. Although financialization is a recent term, the process is far from novel. We conclude that its effects can be studied better with reference to economic history.

Keywords: Financialization; Monetary Regimes; Speculation

JEL Classifications: E42, E44, B52 


\section{INTRODUCTION}

When did financialization start? While there is much literature on the increasing dominance of finance in the United States after 1970, little work to date has attempted to investigate whether financialization was taking place earlier. Whereas few authors consider financialization as an evolutionary process that can be traced back to precapitalist societies, most analysts emphasize the neoliberal period beginning in the 1980s.

Financialization, as Sawyer (2013-14) appropriately describes it, is a process that widely varies in form and intensity across time and space. Accordingly, by utilizing empirical and qualitative analytical tools coming from different schools of thought, we identify distinct phases of financialization during the 20th century in the US. In particular, we examine the resemblance of financialization's characteristics in the early 20th century with those of the contemporary period, questioning whether the current phase of financialization is a vaguely different repetition of its older counterpart, as observed, for example, in the early 1900s.

To carry out our task, we divide the sample period into four distinct regimes, marked by structural breaks in the institutional setting of the economy, which affected the functioning of the financial sector. The first period of early financialization lasts from the beginning of the 20th century up until 1933, as the New Deal agreement brought significant changes in financial regulation and policy orientation. The second period (1933-1940) reflects the transitory phase of the economy that leads to the third period, the "Golden Age of Capitalist Development" (1945-1973). The crisis of 1973 heralded the end of the Golden Age. Lastly, we apply Dumenil and Levy's (2011) definition of neoliberalism as "financialized capitalism" to link the fourth period of complex financialization with 1974-2010.

We contribute to the relevant literature by exploring financialization from a historical perspective and pointing out different varieties of financialization throughout the 20th century in the US. While most studies focus on a few criteria to establish evidence of financialization, we employ a plethora of empirical and qualitative indicators that allow us to formulate a synthetic argument for the pace and the form of 
financialization in each distinct regime. We argue that financialization, characterized by an increased role of the financial sector along with higher complexity across financial objectives and institutions, is merely the current phase of a historical process that has been unfolding since the dawn of the 20th century. In our view, the early 1930s period presents a significant resemblance to the current phase of financialization.

Financialization is associated with financial booms and busts and has a negative impact on the real production of the economy, as it results in unemployment and highlights income inequalities. History shows that the degree of financialization is a policy variable. For instance, in the postwar period, policymakers implemented a range of policy instruments (such as full employment policies of a Keynesian flavor) and enforced a strong regulatory environment in order to restrict the uncontrolled explosion of finance. The implications of our findings could point towards policies that could reverse the destabilizing effects financialization has on society.

The paper is organized as follows: section 2 discusses theoretical contributions with respect to financialization; section 3 looks at the data relating to the financialization process, focusing on the importance of the financial sector; and section 4 provides an analysis of the course of financialization throughout the 20th century, paying close attention to the interaction between financial innovations and the regulatory environment, as well as to the degree of shareholder value orientation in the economy. We also scrutinize the commitment of fiscal and monetary policies to full employment and low inflation targeting. In the penultimate section we examine whether the economic system is prone to financial collapse and summarize our findings, which formulate and support our argument, while the last section concludes.

\section{VARIETIES OF FINANCIALIZATION}

Financialization is a broad concept with multiple dimensions interacting in the economic, social, and institutional domain. The most common definition for financialization is the one provided by Epstein (2005: 1), who refers to the process as "the increasing importance of financial markets, financial motives, financial 
institutions, and financial elites in the operation of the economy and its governing institutions, both at the national and international level." In a similar vein, Vercelli (2013-14: 5) defines financialization as "the process of evolution which has progressively increased the crucial role of money in the economy and society shaping the forms of exchange, circulation, distribution, and accumulation of exchange value."

Although both definitions are rather broad, they capture the complex nature of financialization and its links to the underlying institutional structures. However, the absence of a single criterion that would integrate every dimension of financialization renders the establishment of relevant evidence a rather challenging task for empirical researchers.

The broadness and the importance of financialization led several authors to an investigation of a rather wide scope regarding the origins of the phenomenon, and triggered a debate on whether financialization dates centuries back or if it constitutes a unique phase of the current phase of capitalism. Following Sawyer (2013-14), we identify two large strands of literature on financialization. The first examines the evolution and the size of the financial sector and has its origins in both mainstream and heterodox schools of thought. For instance, Vercelli (2013-14) associates financialization with the penetration of different forms of money in society through financial innovations, and identifies a "secular tendency towards financialization" that originates in ancient civilizations, although he recognizes two distinct phases of financialization in the 20th century. Mainstream authors tend to highlight the positive consequences of financialization, often referring to it as "financial development." They employ several proxies of financialization, such as the size of the economy's banking sector, its loan provision capacity, or measure the relative importance of the financial sector, by going back as far as their data sources allow (see Greenwood and Scharfstein 2013). By contrast, heterodox authors largely examine the destabilizing impact of financialization on the economic and social domain. The second literature strand, deriving mainly from heterodox schools of thought, tends to associate financialization with the era of neoliberalism, which began in the $1980 \mathrm{~s}$ for most developed economies, and describes it as a different form of capitalism in which finance has become more dominant than it previously had been and penetrated in 
various realms of society (Sawyer 2013-14). Table 1 presents some pertinent studies in each approach that are employed in this paper.

Next we provide an overview of several of the listed approaches to financialization, among them, a strand of research that focuses on the submission of the production process to the principles of financial liquidity. For instance, Palley (2007: 2) suggests that financialization is "a process whereby financial markets, financial institutions, and financial elites gain greater influence over economic policy and economic outcomes." This process is characterized by "a slight shift in income toward capital, a change in the composition of payments to capital that has increased the interest share, and an increase in the financial sector's share of total profits" (Palley 2007: 14). Similarly, Orlean (1999) associates financialization with the restructuring of the internal organization of the firm, as a response to the increasingly powerful interests of the stock market.

This approach is close to the view that financialization refers to the increasing power of the rentier class. It derives from earlier works of Hilferding (1910) and Lenin (1916) and has been more recently advocated by Dumenil and Levy (2002) and Epstein and Jayadev (2005). However, this view could be considered as too narrow, as it focuses solely on the rentier class, while currently the firm has become the "battleground" for different agents, including workers, managers, shareholders, and financiers (Stockhammer 2005-06). 
Table 1. Financialization in the Economics Literature

\begin{tabular}{l} 
Approaches \\
\hline \\
Financial Development / Increasing Size of \\
the Financial Sector
\end{tabular}

Pertinent Studies

- $\quad$ King and Levine (1993)

- $\quad$ Rousseau and Wachtel (2000)

- Greenwood and Scharfstein (2013)

- Philippon (2015)

$\begin{array}{lll} & \text { - Arrighi (1994) } \\ & \text { - Epstein (2001) } \\ \text { Increasing Importance of Financial Markets / } & \text { - Dumenil and Levy (2002) } \\ \text { Increasing Power of Financial Elites and } & \text { - Epstein and Jayadev (2005) } \\ \text { Rentier Class } & \text { - Palley (2007) } \\ & \text { - Dallery (2008) } \\ & \text { - Vercelli (2013-14) }\end{array}$

- $\quad$ Arrighi (1994)

- Lavoie (1995)

Regimes of Accumulation / Corporations

- Boyer (2000)

Engaged in Profit Making in the Financial

- Stockhammer (2004)

Sector

- Krippner (2005)

- $\quad$ van Treeck (2008a)

- Hein (2008)

Shareholder Value Orientation

- $\quad$ Lavoie (1995)

- $\quad$ Lazonick and O’Sullivan (2000)

- Aglietta and Breton (2001)

- Cutler and Waine (2001)

- Stockhammer (2004)

- Froud et al. (2006)

- Roberts et al. (2006)

- Dallery (2008)

- Hein (2008)

Financial Innovations / Debt-Led Consumption and Distribution

- Hilferding (1910)

- Palley (1994)

- Phillips (1996)

- Dutt (2005)

- $\quad$ Bhaduri, Laski, and Riese (2006)

- Montgomerie (2006)

- Hein and van Treeck (2008)

- Hein (2009)

- Epstein (2001) 
According to advocates of "shareholder value orientation," the growth pattern of the firm has shifted from "retain and invest" to "downsize and distribute" (Lazonick and O’Sullivan 2000). In particular, shareholders are considered to have a short-term orientation with respect to firms' profits, as they are interested in higher dividend payments and higher stock prices, which is in stark contrast to the managers' aim for long-run growth of the firm. Higher dividend payments imply lower retained earnings, while higher stock prices translate to low equity issuance (Hein and van Treeck 2008). Therefore, financing of investments becomes feasible only through the use of external means, such as higher loans and increased leverage ratios, which render the firms financially fragile.

Close to the shareholder value orientation norm is the definition provided by Arrighi (1994) and Krippner (2005), according to which financialization is a pattern of accumulation, where profit is accrued primarily due to financial activities and less so due to production or trade activities. Arrighi's and Krippner's definitions coincide with the shareholder value orientation view in the fact that productive firms engage in financial activities, either because the expected profit in the financial market is higher than the corresponding profit in the goods market, or because the conditions associated with high dividend payments are so strict that they essentially force firms to seek additional gains in the financial market. As put by Dallery (2008), the profit rate has become "an end in itself." Nevertheless, as noted by several authors, ${ }^{1}$ the impact of this process has ambiguous results on accumulation, with the institutional setting of the economy defining its ultimate goal and the associated regime (Stockhammer 2004).

A considerable amount of research has focused on financial innovations as a feature of financialization. Hilferding (1910) looked at financial derivatives as a tool of capturing the essence of speculation, which lies solely in the exchange value (Sotiropoulos 2012). In addition, Phillips (1996) links the intensity of financial innovation to the volume of trading in the financial markets.

\footnotetext{
${ }^{1}$ See, e.g., Boyer (2000), van Treeck (2008b), Hein (2008), and Lavoie (1995).
} 
Financial innovation has also been extended to the rise of new consumption patterns, bound to higher household debt structures with distributional implications (Palley 1994; Dutt 2005). Hein and Mundt (2013) suggest that stagnating wages are linked to increased household debt and result in debt-led consumption booms, while Bhaduri, Laski, and Riese (2006) focus on the wealth effect on consumption, where higher levels of financial wealth induce households to spend more, given financial deregulation. Lastly, Montgomerie (2006) looks at the introduction of credit cards, which allowed more financial institutions to enter the credit market.

Financialization varies in terms of pace and form, and one can identify periods of financialization as well as of definancialization (Sawyer 2013-14). However, comparing distinct periods of financialization is not an easy task, since "there are too many factors to account for change and capitalism cannot necessarily be characterized by compartmentalized sub-epochs" (Orhangazi 2008: 24). The comparison becomes even trickier, as different schools of thought in economics consider different indicators, proxies, and definitions to measure financialization. In identifying distinct phases of financialization in the US economy, we apply the following methodological statement: We assume that the capitalist system is a prerequisite for the process of financialization, as well as a certain degree of financial development, in the sense that financial instruments become commonplace.

According to Graeber (2011), the evolution of debt instruments can be traced back for 5,000 years, however we select the beginning of the 20th century as our starting point, as it satisfies the following methodological statement: a) US capitalism had already been in place for a significant amount of time; and b) it was a period characterized by a fairly developed financial sector that gave birth to modern consumer credit (Calder 1999; Feretti 2008). Thereafter, we divide the period into four distinct regimes associated with structural breaks in the institutional setting of the economy in order to make comparisons in terms of institutions, polices, and economic outcomes in each period. These structural changes in capitalism did not occur within the period of a calendar year, rather they took place gradually. For this reason, developments during the 1930s and 1970s could only function as proxies of an ongoing change, the effects of which were observed in late 1940s and early 1980s, respectively. 


\section{THE IMPORTANCE OF THE US FINANCIAL SECTOR}

Our analysis begins by looking at the role of the financial sector in economic activity, as measured by a number of criteria addressed in the literature. Figure 1 shows the sum of the profits and wages in the US financial sector as a share of GDP for the period 1900-2012. The upward trend is clearly evident, even from the early 20th century, and is only disrupted by the run-up to WWII. Up until 1933, the increase in the income share of finance more than doubled (111\%), while the associated yearly rate of growth, on average, was about 2.5\%. Between 1934 and 1973, the increase in the income share of finance was much more moderate (46\%), with the yearly growth rate of the share being equal to $-4.3 \%$. Lastly, after 1974 , the US economy witnessed an overall rise in the share of finance by $30 \%$ with a yearly growth rate of $1.01 \%$.

Figure 1. Income Share of Finance in the $\mathrm{US}^{2}(1900-2012)$

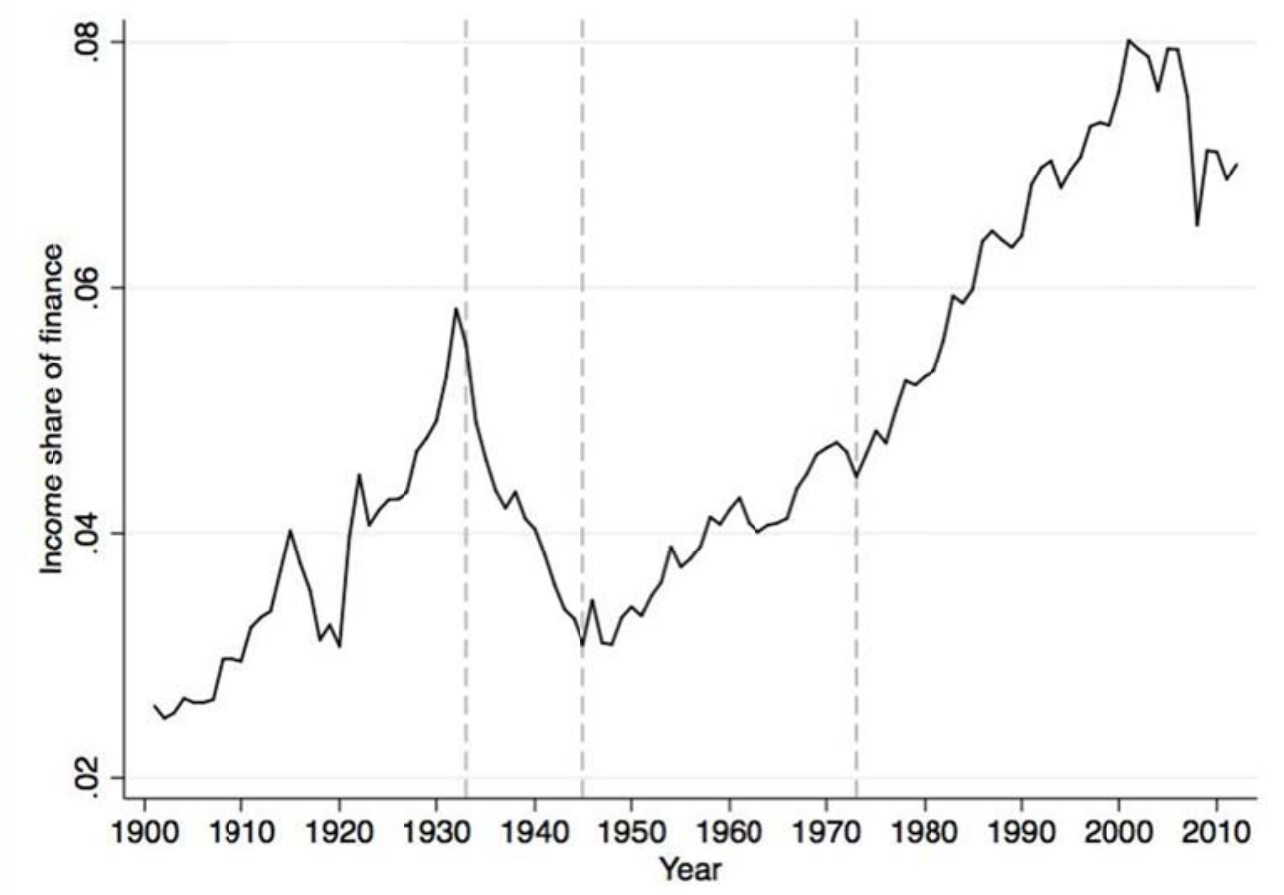

Source: Estimations based on Philippon (2015).

\footnotetext{
${ }^{2}$ The estimations for the income share of finance refer to the value added of the factors of production, while GDP excludes the spending on defense to adjust for the tremendous effect on spending during WWII.
} 
The increasing importance of the financial sector is also depicted by the share of consumption expenditure on financial goods and services, reported in figure 2. Expenditure for financial products in the 1930s was slightly higher than health expenditure and significantly higher than expenditure for medicine. In recent years, finance-related expenditure has grown only moderately compared to other types of expenditure, though the amount is higher in absolute terms.

Figure 2. Consumption by Type of Expenditure as a Share of GDP for the US Economy (1930-2010)

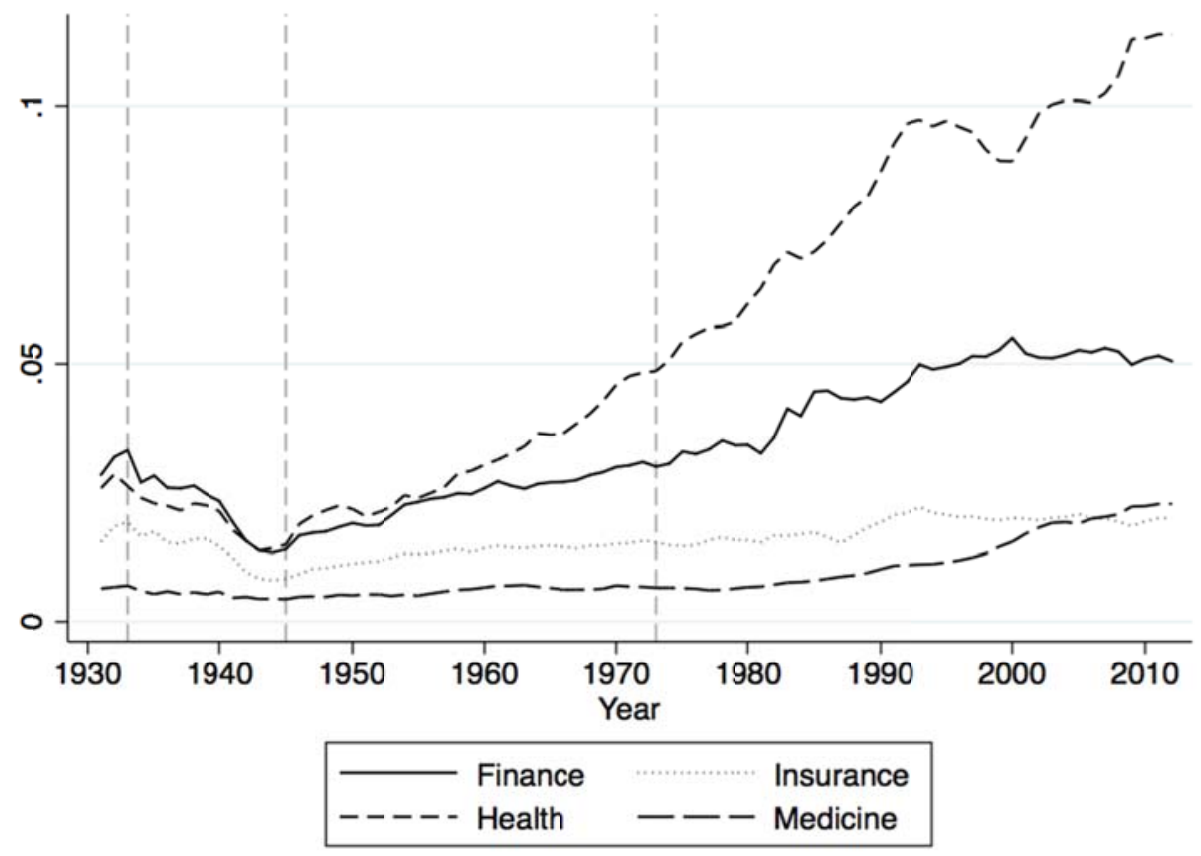

Source: Estimations based on Mehra, Piguillem, Prescott (2011) and Philippon (2015).

Another measure of the importance of the financial sector is its level of sophistication, otherwise known as "financial depth." In the literature, the most common proxy for financial depth is broad money (M2) or the stock of liquid liabilities (M3) expressed as ratios of GDP. Figure 3 shows the ratio of broad money over GDP in the US for the period 1900-2010. Despite the high variability throughout most of the century, broad money over GDP indicates distinct trends across each phase of financialization we explored. The period 1900-33 indicated a relatively steady yearly rate of money growth of around $1 \%$. The period between the financial crash and the beginning of WWII indicated a similar yearly rate of growth, though with extreme fluctuations due 
to the higher uncertainty. ${ }^{3}$ During the Golden Age of capitalism (1945-73) the ratio of broad money to GDP plummeted, with an average yearly decline of $0.6 \%$. The neoliberal phase showed increases in the monetary base of the US economy, especially after 2000 , indicating a yearly growth rate of almost $1 \%$, similar to the first phase of financialization.

Figure 3. Broad Money over GDP for the US Economy (1900-2010)

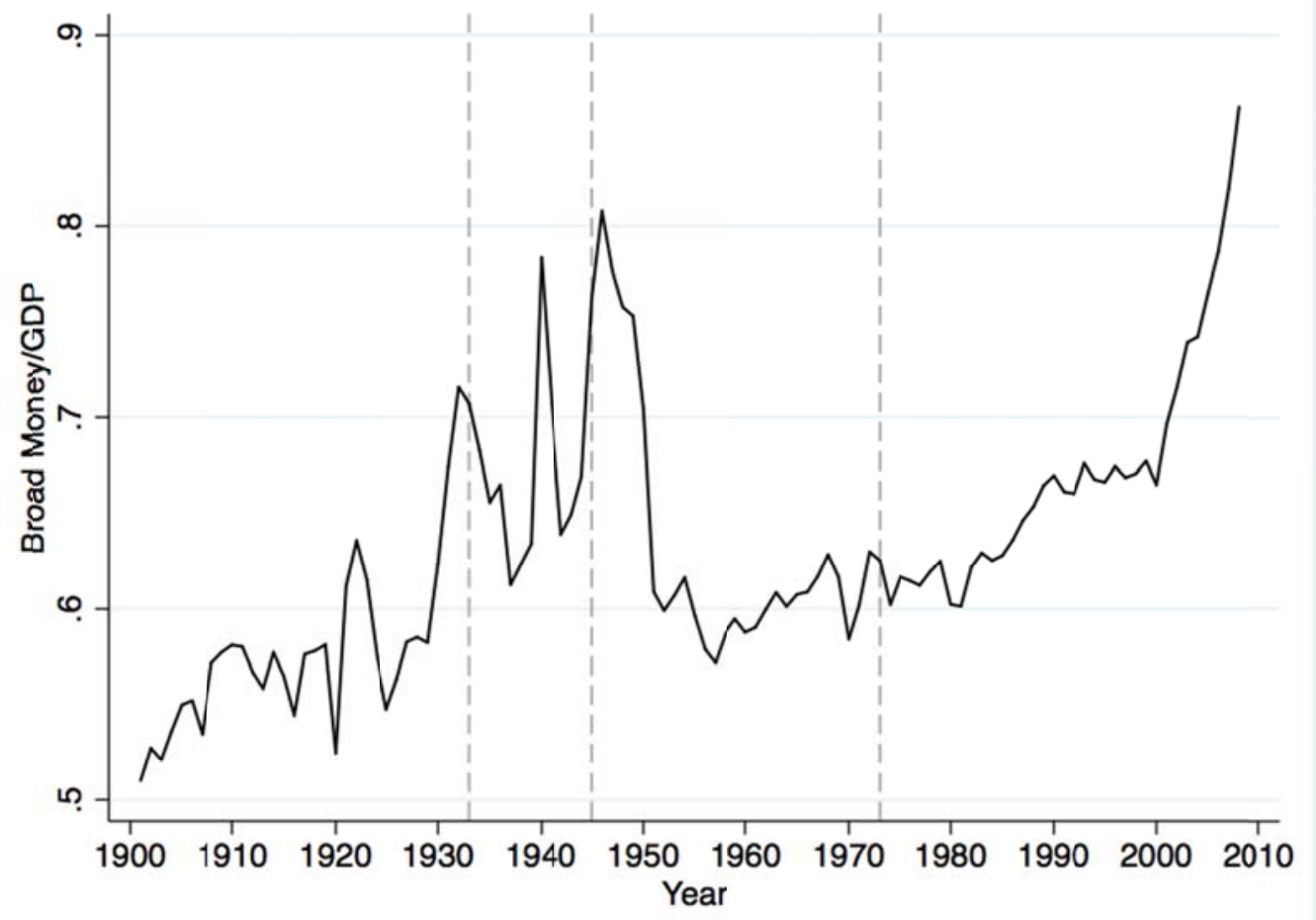

Source: Estimations based on Schularick and Taylor (2012).

These figures provided an overview of US financial development during the 20th century, suggesting that the importance of finance was already prominent in the early 1900 s, i.e., the first period we examine. The following paragraphs track the evolution of financialization in depth using methodological instruments derived mainly from the post-Keynesian tradition.

\footnotetext{
${ }^{3}$ The fluctuations could be explained by high uncertainty, which, as pointed out by Keynes (1936), leads to hoarding of money.
} 


\section{EVIDENCE OF FINANCIALIZATION IN THE US ECONOMY IN THE 20th CENTURY}

In this section we use empirical estimates to assess the relative importance of finance throughout the 20th century in the US economy. Similar attempts have been carried out by several authors. Among them, Krippner (2005) constructed two indicators for financialization for the post-WWII period. Her first indicator relates to the ratio of profits of corporations stemming from financial activity, while the second compares the profits between the financial and the productive sectors. Both of these indexes provide support for the rise of financialization in the 1970s. However, due to data limitations, the analysis did not include the interwar period.

Stockhammer (2004), by dividing the share of interest and dividend payments by the share of profits, empirically tested the hypothesis that short-run investment in financial instruments is preferred to long-run investment in real capital. His hypothesis is rejected for Germany and perhaps the UK, but is valid for France and the US. Van Treeck (2008b) employed a Kaleckian growth rate of investment function for the US to find that interest and dividend payments have a significant negative impact on accumulation, while Orhangazi (2008) found that on a micro-firm level, financial profits have a negative impact on large firms but a positive one on small firms, as financial profits relax the financial constraints.

These attempts vary in methodology and in each sample's period, yet they reach similar conclusions. However, none of the above extends its analysis prior to WWII. In the following subsection, we attempt to shed some light on issues related to financialization throughout the 20th century in the US, with the use of descriptive statistics.

\subsection{Shareholder Value Orientation}

The shareholder value orientation can be viewed as the pressure on managers to ensure short-term profits at the expense of firms' long-run growth. By using this approach, the similarities between the first and the fourth periods of financialization are striking. 
The rise of the joint stock company in the first period provided financial institutions with the option to control corporations by placing their representatives on corporations' boards, by holding their stocks, and by the provision of higher loans (Orhangazi 2008: 24). As an immediate result of this condition, financing capitalists were actually monitoring managers (DeLong 1991). From a similar point of view, the productive capital was financialized (Pineault 2001, cited in Orhangazi 2004: 27), which, in combination with the developments in the stock market, had a detrimental impact on the sustainability of the economic system (Keynes 1936: 160).

The overall switch in the mentality of entrepreneurs towards the pursuit of prospective, and even speculative, profit as compared to the mentality of the entrepreneurs in the late 19th century was already noted by Keynes (1936: 159) in the interwar period.

The intense regulation and interventionist policies in the second period paid off in the third, where the boom in fixed capital formation signified a transition towards a longrun orientation with respect to firms' growth (Marglin and Schor 1990). Overall, this period was characterized by financial tranquility, where the pressure on managers, by financiers and stockholders, was reduced (Orhangazi 2008: 30).

However, in the last period, this pressure once again resurged, in a rather "formal" manner, as compared to the first one. For instance, the imposition of the so-called return-of-equity (ROE) norm was indicative of the ultimate goal of management, which was to maximize the return value to shareholders.

To proxy the level of shareholder value orientation, we focus on the controversy that arises between the dividend payments and the internal financing of investments. ${ }^{4}$ Table 2 presents the average shares of net dividend payments and retained earnings over corporate profits after tax. The first period spans from 1929 to 1932; therefore, the related values are a mere reflection of the irregularity of the Great Depression,

\footnotetext{
${ }^{4}$ Possibly the most notable feature of the shareholder value orientation relates to the increasing shortrun investment in financial assets at the expense of investing in real assets (Stockhammer 2004).

Nevertheless, due to data limitations regarding interest payments between sectors, we were unable to assess this feature for the period under examination.
} 
where corporations were distributing sums that exceeded their profits, presumably to sustain the price of their shares.

However, the blurred depiction of the first period is somewhat restored in view of the second period, where no dramatic changes in the institutional framework of the associated variables were observed. Specifically, distributed profits accounted for more than $80 \%$ of the overall profits, implying an overwhelming "originate and distribute" orientation (Sawyer 2013-14).

This condition is reversed in the third period, with retained earnings accounting for $60 \%$ of profits, which comes in line with the investment boom in the Golden Age. However, in the latest period, the pressure on managers is depicted in the higher share of net dividends, accounting for $55 \%$ of profits. In advance, the intensity of the distribution of profits becomes higher in the period close to the Great Recession. For instance, the average shares of net dividend payments and retained earnings in the period between 1995 and 2008 were equal to $64 \%$ and $36 \%$, respectively.

Table 2. Average Share of Net Dividend Payments and Retained Earning to Corporate Profits after Tax (excluding Depreciation Allowances) in the US

\begin{tabular}{lll}
\hline & Dividends & Retained Earnings \\
\hline 1st Period & 10.41 & -9.39 \\
2nd Period & 0.87 & 0.13 \\
3rd Period & 0.39 & 0.61 \\
4th Period & 0.53 & 0.47 \\
\hline
\end{tabular}

Source: National Income and Product Accounts

Subsequently, we examine corporations' external debt, paying much attention to the corporate bond and equity issuance. Corporate bond issuance, depicted in figure 4a, presents high volatility in the first period of financialization, yet it fluctuates at a considerably higher level than equity issuance. This pattern is followed in the second period; in the third, bond issuance stabilizes around $1.5 \%$ of GDP, to explode in the latest phase of financialization. 
Figure 4a. Gross Equity Issuance and Gross Corporate Bond Issuance over GDP for the US Economy (1910-2010)

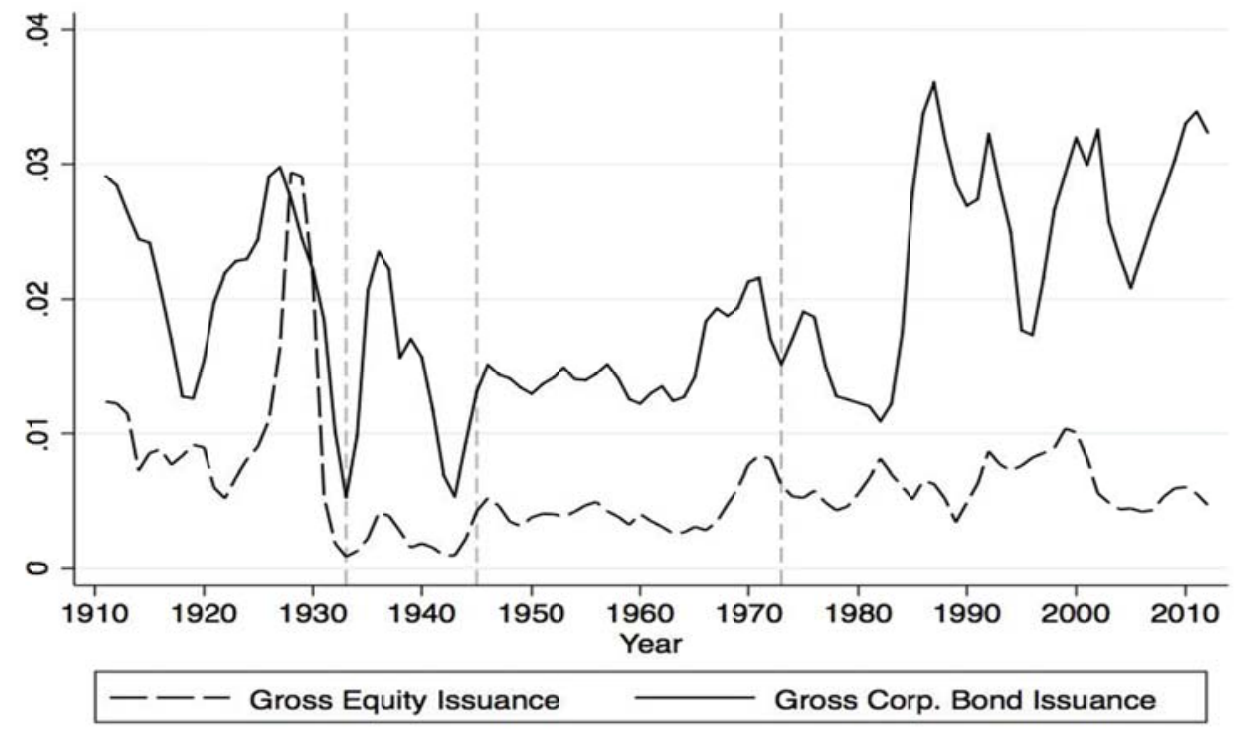

Source: Estimations based on Baker and Wurgler (2000) and Philippon (2015).

Figure 4b. Market Value of Equity over GDP for the US Economy (1900-2012)

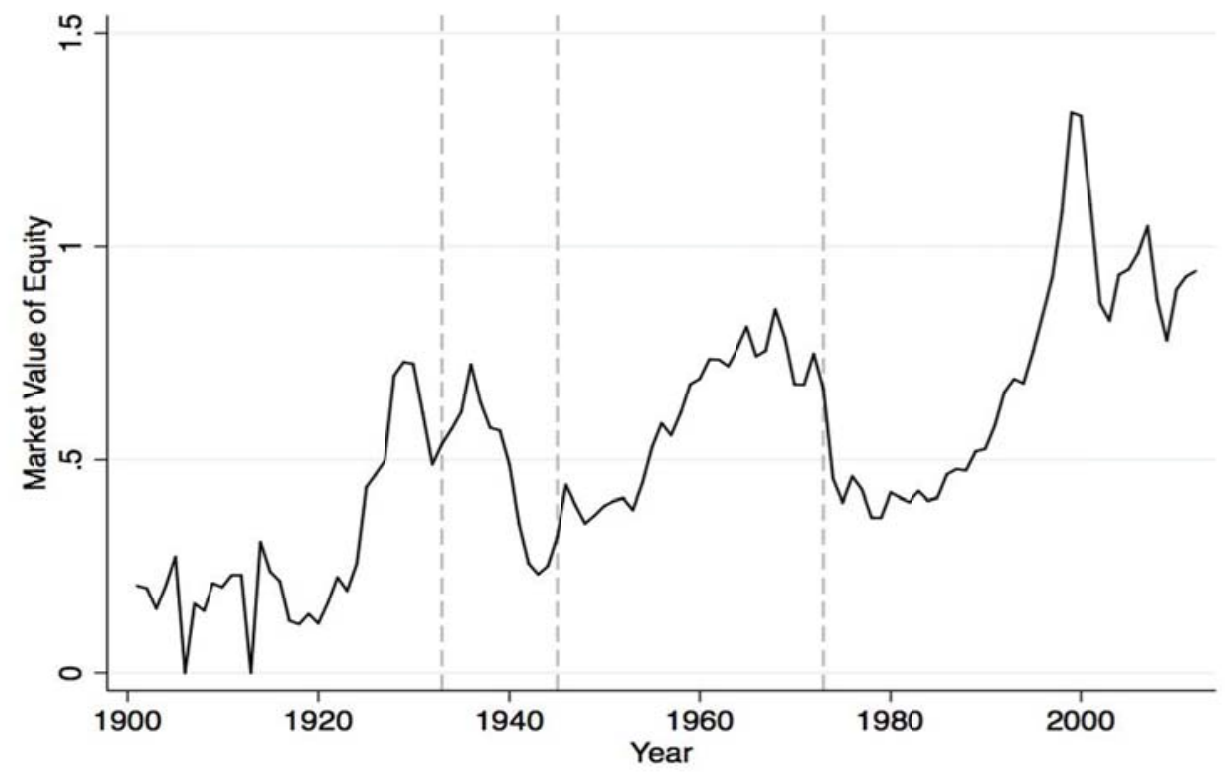

Source: Estimations based on Baker and Wurgler (2000) and Philippon (2015).

With respect to equity issuance, there was a clear negative trend close to the 1920 s, where an extreme short-term rise took place due to the stock market rally, as reported in the abrupt increase of the market value, which led to the financial collapse in 1929. After the WWII, equity issuance remained relatively stable, with a small increase in 
the average level in the fourth period, while following a cyclical pattern. On the contrary, the market value of equities presented both an upward sloping trend and a cyclical pattern, with a widely increasing volatility of the latter. These are well illustrated in table 3, which provides an overview of the average bond and equity issuing and the corresponding volatilities for each period.

Table 3. Corporate Gross Bond Issuance and Gross Equity Issuance over GDP for the US Economy (1909-2012)

\begin{tabular}{lllll}
\hline & \multicolumn{2}{l}{ Gross Bond Issuance over GDP } & \multicolumn{2}{l}{ Gross Equity Issuance over GDP } \\
\hline & Mean & Volatility & Mean & Volatility \\
\hline $\mathbf{1}^{\text {st }}$ Period & $2.25 \%$ & $25.24 \%$ & $1.09 \%$ & $62.13 \%$ \\
$\mathbf{2}^{\text {nd }}$ Period & $1.62 \%$ & $38.24 \%$ & $0.24 \%$ & $51.17 \%$ \\
$\mathbf{3}^{\text {rd }}$ Period & $1.51 \%$ & $17.59 \%$ & $0.44 \%$ & $34.55 \%$ \\
$\mathbf{4}^{\text {th }}$ Period & $2.41 \%$ & $31.10 \%$ & $0.62 \%$ & $37.64 \%$ \\
\hline
\end{tabular}

Source: Estimations based on Baker and Wurgler (2000) and Philippon (2015).

Lastly, we focus on mergers and acquisitions, which according to Hein (2009) reflect the pressure on managers by the use of hostile takeovers. Figure 5 depicts the value of mergers and acquisitions for the period 1900-2013. The intensity of merger activity is clearly evident during the 1920 s, followed by a period of tranquility after the financial collapse of the late 1920s. However, after the late 1960s, and especially around the millennium, a second explosive wave of mergers takes place.

Figure 5. Value of Mergers and Acquisitions in the US (1900-2013)

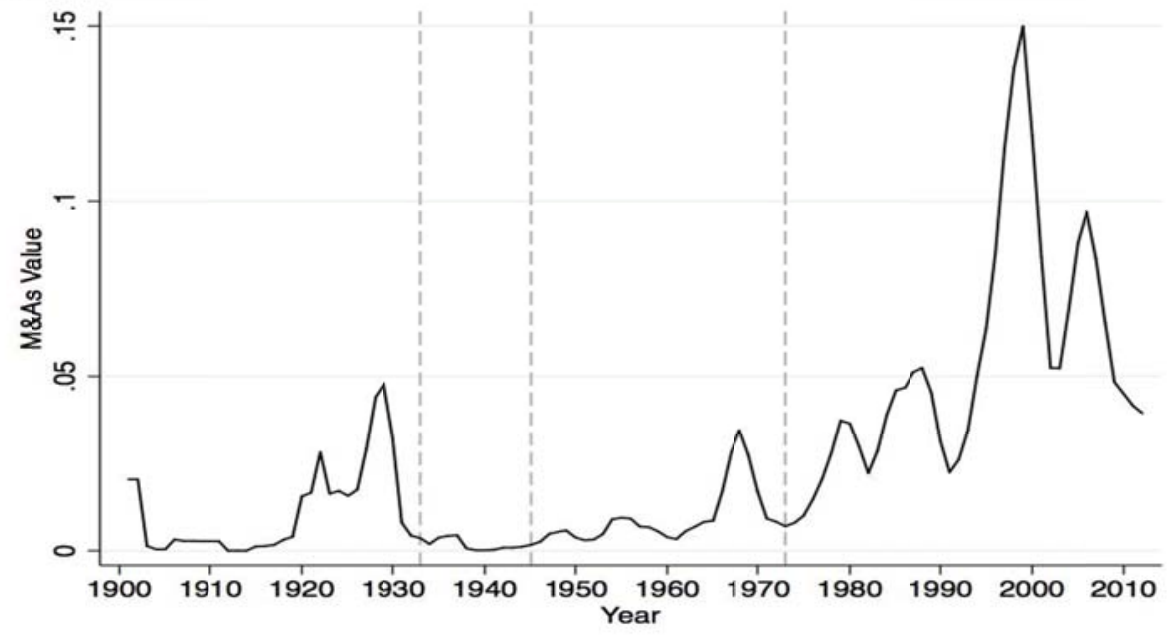

Source: Estimations based on Jonanovic and Rousseau (2005) and Philippon (2015). 
Overall, evaluating shareholder value orientation in a consistent manner is not an easy task, given the data limitations and the distinct institutional framework in each period. However, our analysis suggests that common elements are present between the first and the fourth period under consideration, providing support for the argument in favor of financialization in the early 1900 s.

\subsection{Financial Innovations, Regulatory Framework, and Household Credit}

\subsubsection{Financial innovations growth rate}

Financial innovations stand at the core of financialization, as they allow the financial sector to overcome regulatory barriers and therefore increase its relative economic power (Bhaduri 2011). Until recently, numerous authors perceived them as a contributor to economic development and prosperity (Bernstein 1996), as they "increase risk sharing, lower transaction costs, and reduce information and agency costs" (Merton and Perold 1997: 108). Only a few scholars highlighted the other side of the coin. One of them was Hyman Minsky (1990: 60), who stressed that "economies with financial innovations that are driven by market prospects are structurally conducive to booms and busts."

The quantitative assessment of the role of financial innovation as contributing factor to the financialization process is a complicated task, as it is not possible to point out which innovation contributed to what extent to the process. Figure 6 represents the share of financial patents registered in the US economy as a share of all registered patents in the country for most of the 20th century as a proxy of the relative share of growth of financial innovations. 
Figure 6. Patents on Inventions and Trademarks in Finance as a Share of All Patents Registered in the US (1900-96)

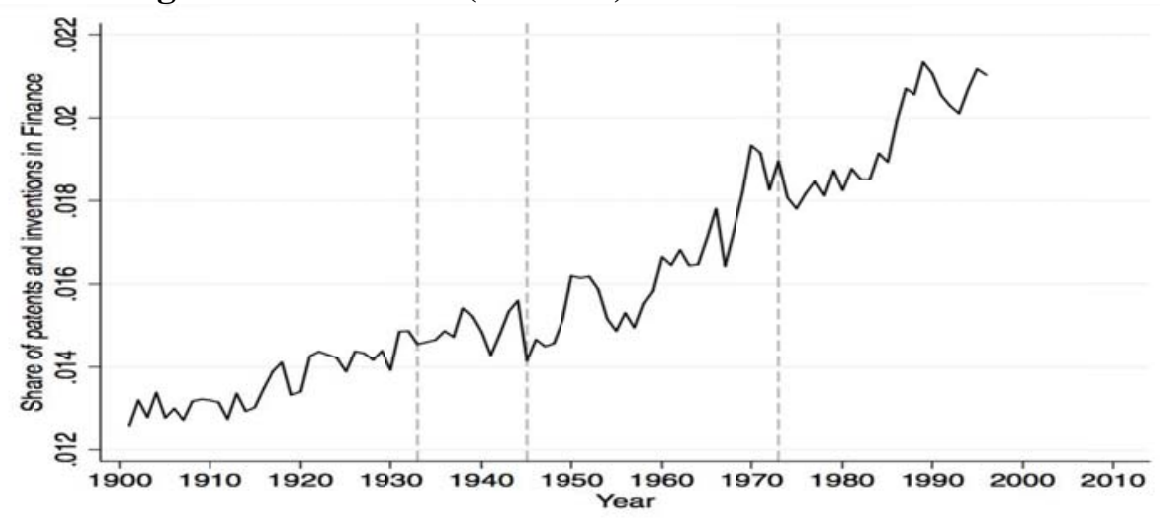

Source: Estimations based on Jonanovic and Rousseau (2005).

It is evident that the trend of new financial patents is steadily increasing throughout this period, representing what Minsky (1986) described as an internal process of a capitalist system with a sophisticated financial sector. This steady rate of growth in financial innovation suggests that the links between financial innovation and financialization should not be rooted in technological improvement per se. Instead, we argue that the institutional and policy forces, which allow the financial innovations to be employed by the financial institutions, are more important. To assess the contribution of financial innovations in the expansion of the financial sector's role in each period, we track preceding innovations moving in tandem with regulatory developments in the domain of finance throughout the 20th century.

\subsubsection{Regulatory framework}

The banking sector's involvement in securitization has been extensively regulated since the mid-19th century. However, a loophole in the associated regulatory framework allowed national banks to enter the securities market by setting up affiliated trusts (White 1986). Numerous banks had already broadened their operations through their bond departments; nevertheless, the growing securities market seemed at that time a source of considerable profit, in which traditional banks were not allowed to participate (White 1986). The introduction of affiliates as an institutional partner of the commercial banks allowed the latter to overcome regulation and gain access to this profitable market. The number of US national banks engaged in securitization was eleven times higher in 1931 compared to 1921, while 
the banks that were mostly interested in the bond market rather than commercial activity more than doubled (Peach 1941). The participation of banks and their affiliates in bond issuing rose from $36.8 \%$ to $61.8 \%$, while the share of bonds issued by all banks increased from $22 \%$ to $44.6 \%$ (US Senate 1931 , cited in White 1986). A contributing factor was also the increased competition for deposits (White 1986). According to Dymski (1991), during the 1920s, immense competition for deposits increased interest costs, leading banking institutions on a quest for high return, i.e., riskier loans.

The higher leverage structure also served the purchase of stocks, which implies higher stock prices and, therefore, capital gains. Speculation during the 1920s rendered the US economy financially fragile. The intensive securitization, with the use of uninsured deposits as collateral in combination with the stock-market rally, led to the stock-market crash in 1929.

The outbreak of the Great Depression was followed both by interventionist policies and legislative initiatives, which aimed to prevent any further deterioration of the economy and control the potentially destabilizing threats of the financial activity in the productive sector. The most critical policy response with respect to the functioning of the financial sector was the Glass-Steagall Act, passed in 1933.

Specifically, policymakers were particularly concerned with the involvement of banks in the securities market, as they were identified as one of the major causes for the massive bank failures during the Great Depression (Crawford 2011). For this reason, banks were offered the choice to engage in either commercial or investment banking activities. The introduction of the Federal Deposit Insurance Corporation (FDIC) ensured the protection of depositors from defaults in commercial banks, while the newly established Securities and Exchange Commission (SEC) regulated financial practices.

The intense regulation, in combination with weak foreign competition, resulted in financial tranquility, where the pressure on managers by financiers and stockholders was reduced (Orhangazi 2008: 30). 
In the first two decades after WWII, the US economy achieved an almost full employment state, experiencing only minor recessions and modest inflation periods (Minsky 1986), while financial activity was carried out under the control of the Fed with the use of the Fed's discount window and open-market operations (Minsky 1986).

However, the institutional changes in the financial sector and, in general, the attempts to regulate its functioning lacked a coherent theoretical framework that would allow for a dynamic and continuous regulating process (Minsky 1986: 43-45). This argument is verified by the fact that during the 1960s, a period characterized by strong investment growth, financial innovation in the money market-i.e., by introducing the certificate of deposits, real estate investment trusts (REITs), and the commercial paper-rendered the Fed's controlling instruments ineffective, since the latter were not adapted to the new financial environment.

More importantly, the structure of debt had a critical role in the period at hand. As a follow-up to the Great Depression, government debt started rising and even surpassed private debt during WWII, reaching a record level of $113 \%$ of GDP (see figure 7). Indeed, it was the first time that public debt penetrated into firms' and households' balance sheets as a financial asset (Minsky 1986:37-38). 
Figure 7. Total Debt-to-GDP, Private-debt-to-GDP, and Government-debt-toGDP for the US Economy (1900-2012)

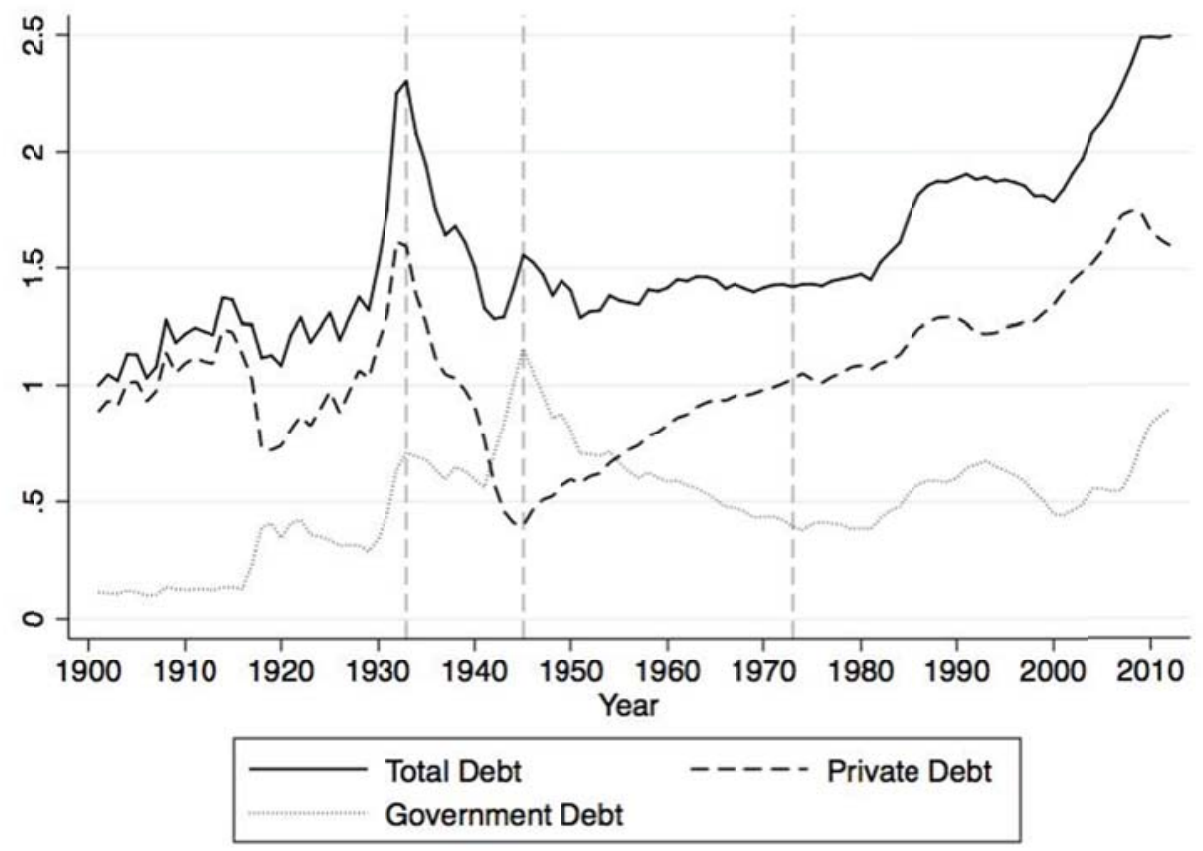

Source: Estimations based on Philippon (2015).

A seemingly financially tranquil period was disrupted by a wave of financial episodes. Minsky (1986) described in detail the developments in the financial sector that led to the credit crunch of 1966 and the liquidity squeeze in 1969-70. Focusing particularly on the money market, financial institutions collateralized the liability side of their balance sheet for the first time after WWII; this resulted in high levels of instability in the financial sector and reduced financing of tangible capital investments. Also, rising public debt in the hands of the public and other financial institutions, along with an increasing rate of financial innovations, suggests a deeply rooted transformation that consequently resulted in a debt-oriented financial environment during the neoliberal era of financialization (fourth period).

In 1975, the Securities Amendment Acts were passed in order to set up the National Market and the National Clearing System, aimed at enhancing liquidity and competition, yet they failed to deliver results (Komai and Richardson 2011). In the same year, the fixed minimum commission rates were repealed as anti-competitive regulation. 
In the 1980s, a large-scale deregulation process took place, with the Glass-Steagall Act being gradually relaxed by the Fed ${ }^{5}$ and eventually repealed in $1996^{6}$ (Crawford 2011). At the same time, US financial institutions, keen on becoming aggressively competetive on a global scale, lobbied for loose regulation (Komai and Richardson 2011). Finally, the reform of FDIC to FDICIA (Federal Deposit Insurance Corporation Improvement Act), in 1991, institutionalized the "too big to fail" doctrine (Komai and Richardson 2011). The remaining regulations were carried out on the basis of addressing moral hazard and information asymmetries.

\title{
4.2.3. Household indebtedness
}

Today, perhaps the most notable example of financial innovations affecting the macroeconomic environment is household credit. For instance, Palley (2007: 24) suggests that:

\begin{abstract}
Borrowing is also supported by steady financial innovation that ensures a flow of new financial products allowing increased leverage and widening the range of assets that can be collateralized. Additionally, credit standards have been lowered in recent years, which has made credit even more easily available to households, firms, and financial investors.
\end{abstract}

Figure 8 depicts the fluctuations in household debt as a percentage of income throughout the 20th century. Household debt peaked at almost $60 \%$ of GDP in the early 1930s (the first period of financialization), a record that had not been surpassed until the mid-1980s. Later on, the accumulation of secured debt progressed sharply and reached a peak at the origins of the subprime crisis, when mortgage borrowing collapsed along with real estate prices.

It was the early 1900 s that gave birth to what is known today as modern "consumer credit.” As reported by Feretti (2008: 17), two innovations in consumer credit, identified during the 1920s were the following: "a peculiar method for credit based on the instalment plan, where money is lent or a good is sold on the condition that the borrower or purchaser repays the loan with fixed payments to be made at regular

\footnotetext{
${ }^{5}$ According to Crawford (2011) the Fed reinterpreted the Act in the 1980s, allowing commercial banks to have 5\% gains from holding securities. The threshold was further relaxed to $10 \%$ by the end of the decade and in 1996 the margin was set to $25 \%$.

${ }^{6}$ Officially the Glass-Steagall Act was abandoned in 1998.
} 
times over a specified period" and "an array of particular sources of credit other than the traditional historic pawnbrokers and/or illegal money lenders."

Figure 8. Household Debt to GDP and Income Inequality for the US Economy (1912-2012)

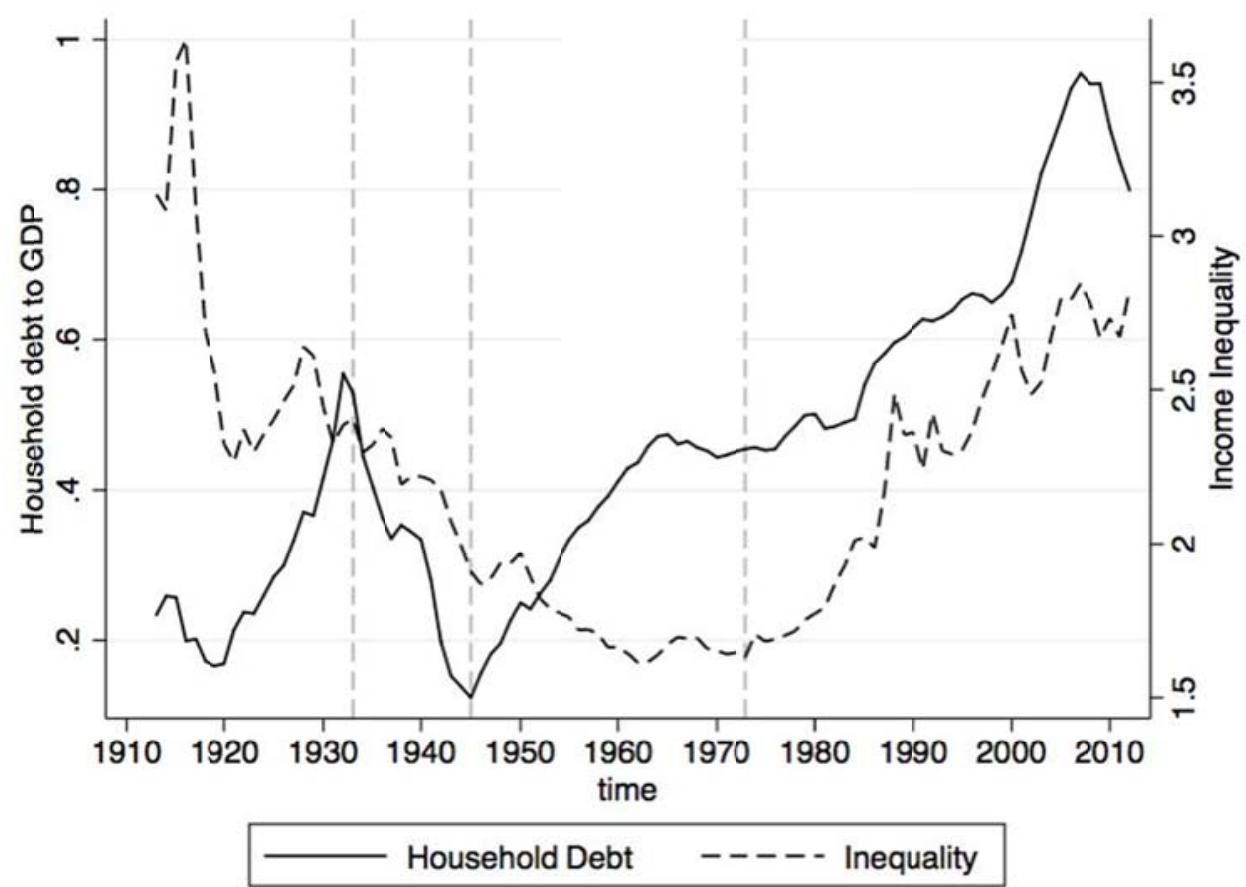

Source: Estimations based on Philippon (2015) and The World Top Income Database.

The levels of household credit in the economy were also noteworthy in the early 1930s. As Calder (1999: 18) indicates:

\begin{abstract}
American household finance was remade after 1915 [leading to...] rising level[s] of consumer debt [...] personal debt increased at rates well ahead of the rate of population growth [...] From 1920 to 1929 , the volume of consumer debt soared upward 131 percent, from $\$ 3.3$ billion to $\$ 7.6$ billion outstanding. The Depression interrupted this rising curve, but by 1937 consumer debt reached its pre-Depression levels and continued rising upwards, until it was halted by credit controls during World War II.
\end{abstract}

However, in contrast to today's consumer borrowing, debt was hardly used for consumption of nonessential things or goods of minimum value. Instead, it was primarily used for purchases of assets with increasing value or with productive purposes (Feretti 2008). 
Possibly the most notable innovation boosting household credit is the promotion of risk management techniques. Asymmetric information (moral hazard and adverse selection) in the credit market reduces lenders' ability to estimate the capacity of borrowers to service their debts. Indeed, the primary aim of risk management is to handle this risk of default (Langley 2008). As such, risk management allows for greater credit expansion with supposedly minimal risk to the resilience of the financial system.

Until the third period under examination, the risks involved in the process of collateralized and consumer borrowing were monitored primarily through relational and "face-to-face practices" (Leyshon and Thrift 1999). Contemporary techniques in risk management (e.g., credit reporting and scoring) removed the physical proximity hitherto required for managing such uncertainties (Guseva and Rona-Tas 2001; Marron 2007). A typical example of higher sophistication in the credit market is the launch of risk-based pricing, in other words, the tailoring of the loan's price to a borrower's probability of default, with the borrower's probability being estimated upon their past credit records. Lastly, advancements in marketing techniques for advertising financial products increased the customer base of banks and other financial institutions (Bertrand et al. 2010).

Indeed, financial liberalization played a large role in unlocking the landscape so that financial innovations could come into play. A direct effect of financial liberalization was the large-scale removal of credit constraints for a big portion of households. The process of removing credit constraints was termed the "democratization of credit" by former Federal Reserve Governor Lawrence Lindsey in 1997, as it reflects the increasingly wider access to credit by middle- and lower-income households. While the extent to which credit constraints are binding varies over time, across countries, and across financial institutions within each country, their presence has a considerable effect on the composition and magnitude of debt holdings on balance sheets of households (Kent, Ossolinski, and Willard 2007). 


\subsection{Fiscal and Monetary Policy}

In this subsection, we examine monetary and fiscal policy with respect to the financialization process. In particular, we assess the role of fiscal policy in promoting full employment and question whether monetary policy has been accommodative to the financial sector.

In the first period under examination, the global monetary system was dictated by the "gold standard," which included movements of gold between central banks, as a response to international non-financial transactions (Eichengreen and Temin 1997). The aim of the gold standard was to secure price stability and constrain fiscal expansion, reflecting "the mentality and the type of conduct of $[. .$.$] economic elites"$ (Eichengreen and Temin 1997).

This condition had a considerable effect on the money supply and the balance sheet of the central banks. As shown by Godley and Lavoie (2007), the system favored the exporting countries, since a deficit in the current account of the importing country implied a reduction of gold reserves of the central bank, which ought to be counterbalanced by an increase in the Treasury bills held by the central bank. This effect gave rise to the twin deficit phenomenon in the importing countries. Given that governments did not favor budget deficits, another option for rebalancing the current account was deflating the economy, with the main burden being laid upon wages, as was the case before WWI (Eichengreen and Temin 1997).

In the US, the lack of a central monetary authority controlled by the government prior to 1913 allows us to safely assume that the interests of the financial sector were de facto accommodated. Financial regulation, carried out by the state governments, could be hardly thought of as effective (Komai and Richardson 2011). In regards to foreign competition and imposed imbalances by the gold standard framework, the current account deficit at the turn of the century was reversed to a surplus in the run-up to WWI, since UK's major supplier of war machinery was the US (Arrighi 1994). This tendency was further heightened after WWI when the US experienced massive inflows of capital due to its strong productivity growth as compared to major European countries, as well as the uncertainty created by the inability of the latter to honor their debt commitments (Arrighi 1994). 
In this context, the specific conditions of that time favored the US financial sector; however, in terms of monetary policy, the outcome is ambiguous. Although there are considerable elements in favor of an accommodative monetary policy, they arguably do not suffice to reach reliable conclusions. Nevertheless, in regards to fiscal policy, non-commitment to full employment was clearly evident.

The fiscal policy inaugurated under the leadership of Franklin Roosevelt in 1933 marked a regime change in terms of policy goals, when a set of acts was implemented to combat recession and unemployment. According to Papadimitriou (2008), these fiscal interventions were a close approximation to an employer of last resort policy, even though they did not succeed in rendering the demand for labor inelastic.

After WWII, the new system that emerged under the Bretton Woods Conference agreement, reflected the dominance of the dollar currency and, hence of the Fed in the global monetary framework. The agreement was accompanied by a set of policy goals, in which the maintenance of full employment had a central role, while the monetary policy was bound to serve the fiscal (Marglin and Schor 1990). Particularly for the US, we observe a clear detachment from processes related to financialization.

Nevertheless, the collapse of Bretton Woods brought flexible exchange rates, while the new political agendas set forth by Thatcher and Reagan in the 1980s gradually led to central bank independence, zero inflation targeting, and the abandonment of full employment.

According to Palley (1999: 106) central banks were characterized by a clear deflationary policy bias. Given that the majority of the board members were previously employed in the financial sector, the institutionalization of central bank independence implied the promotion of financial interests by the monetary policy. In addition, Palley (1999: 120) refers to three regimes of monetary policy in a Phillips curve: a) high inflation and low unemployment, which implies high bargaining power for labor, b) moderate inflation and unemployment, which boosts aggregate demand in the short-run, with moderate inflation reflecting sufficient demand; and c) low inflation with high unemployment, which favors the financial sector. In this context, 
zero inflation policies and central bank independence promote the interests of the financial sector against labor and productive capital.

Overall, the fiscal and monetary framework of conducting policy experienced dramatic changes within the 20th century, where a phase of free market orientation was succeeded by a policy regime in which the fiscal instruments had a critical role in economic activity. The roots of this change are traced both in the economic and the political sphere; however, free market orientation resurged in the latest phase of financialization, with its main features in terms of policymaking resembling those in the early 1900 s.

\section{ASSESSING THE FINANCIALIZATION PROCESS IN THE US ECONOMY DURING THE 20th CENTURY}

In this section, we evaluate the preceding analysis to formulate an argument in favor of or against the existence of financialization in the periods under consideration.

Before taking a final step in our analysis, we examine a last condition for the aggregate economy, related to the leverage structures of banks and corporations. In particular, we follow the notion provided by the two most distinguished authors of the Old Institutionalist School, namely Veblen (1904) and Minsky (1986), who both highlighted the inner tendency of the macrofinancial system towards financial fragility, due to the imposition of increasing leverage, which renders the economic system prone to financial collapse (Argitis 2013).

Figures $9 \mathrm{a}^{7}$ and $9 \mathrm{~b}$ present the leverage ratios of the non-financial corporations and the banking sector. ${ }^{8}$ It is evident that both sectors follow a similar pattern in terms of building leverage structures: enormous debt in the first period, equally massive deleveraging in the second, upwards tendency of leverage in the third that continues

\footnotetext{
${ }^{7}$ The sample period of the leverage ratio of non-financial corporations does not cover the whole last phase of financialization, yet the upward trend is quite obvious.

${ }^{8}$ With respect to the leverage ratio of the banking sector, we follow the definition of Schularick and Taylor (2012).
} 
in the last period, reaching unprecedented levels and thus dramatically increasing financial fragility.

Figure 9a. Leverage Ratio of US Non-financial Corporations (1926-96)

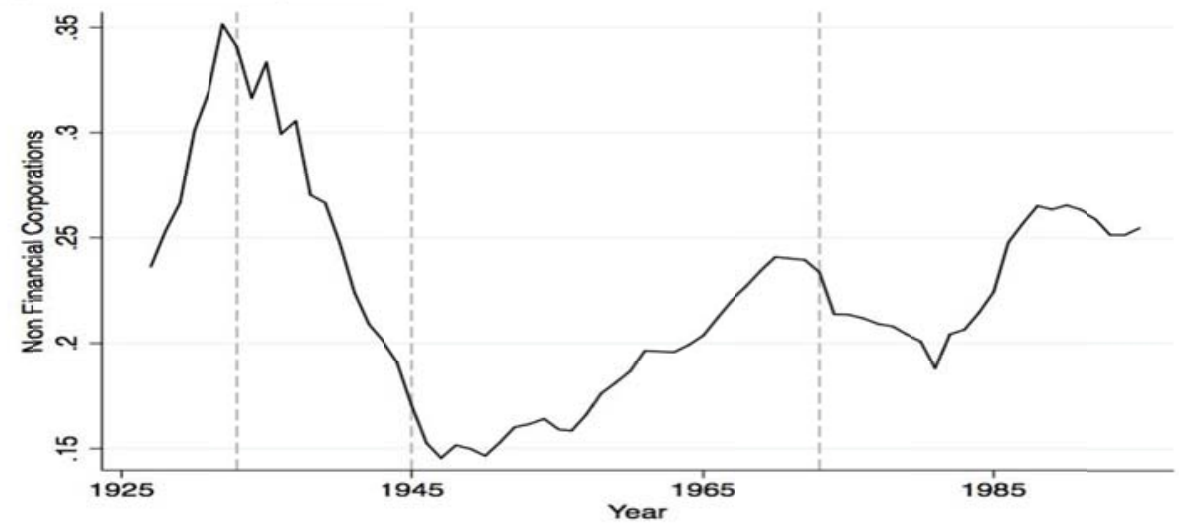

Source: Estimations based on Schularick and Taylor (2012) .

Figure 9b. Leverage Ratio of the US Banking Sector (1900-2010)

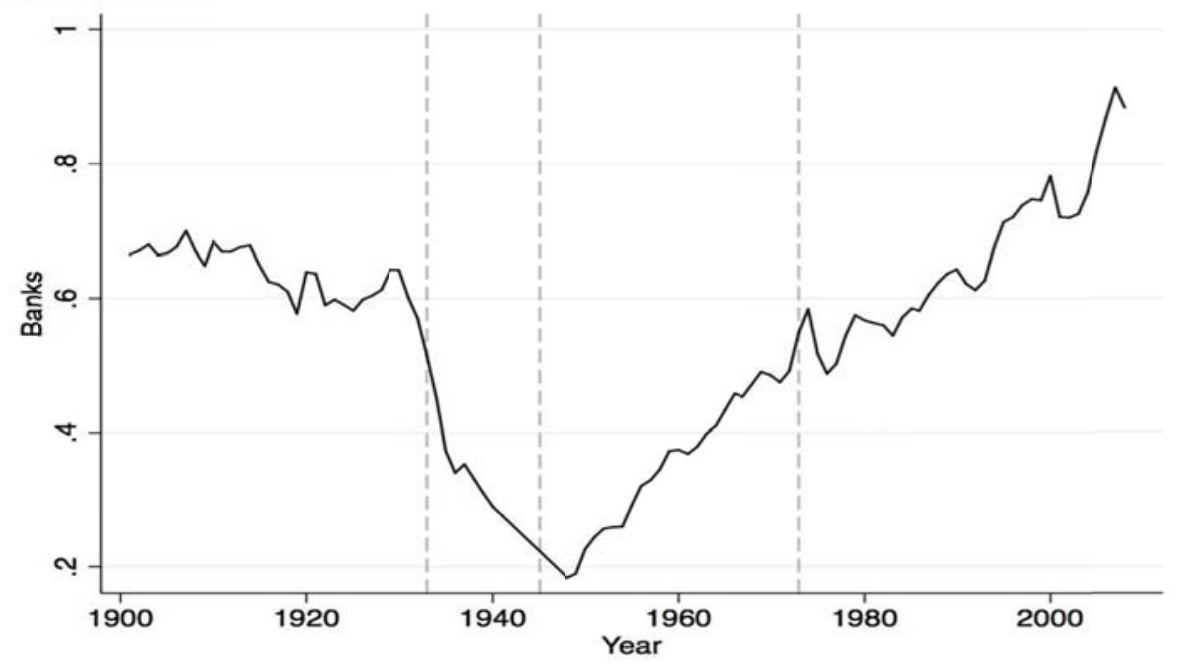

Source: Estimations based on Schularick and Taylor (2012).

Figure 10 presents the frequency of financial crises between 1870 and 2012. Although it refers to financial crises on a global scale, the importance of the US financial sector in the global economy during the 20th century is such that most of the important financial episodes were domestic. In particular, the most severe financial crises (those of 1906-07, 1929, and 2007-08) occurred in the US. It is worth noting that the lowleverage period, evident in figures $9 \mathrm{a}$ and $9 \mathrm{~b}$, coincides with financial tranquility, and 
is located mainly in the Golden Age, thus providing evidence for Veblen's and Minsky's analyses.

Figure 10. Global Financial Crises (1870-2012)

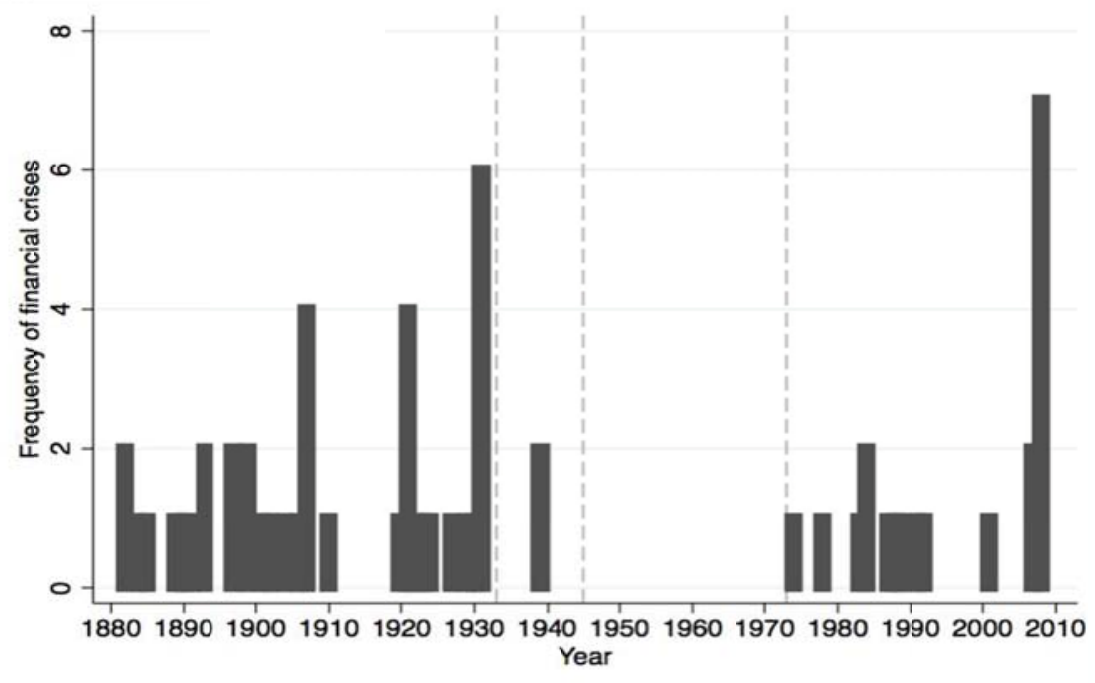

Source: Estimations based on Schularick and Taylor (2012).

Table 4 presents our findings. Each row denotes a charachteristic of financialization and each column the corresponding period. Note that the bar in the cells indicates that the examination of data and characteristics could not provide conclusive results.

It is straightforward from the table that during the first period under consideration key features of financialization (such as the dominance of the financial sector over the economic activity, financial deregulation, shareholder value orientation, and household indebtedness with distributional effects) were already in place, thus justifying the notion of a period of early financialization. In the third period, the conditions are clearly reversed, with most features highlighting the ongoing process of definancialization. The end of the Golden Age initiated a second wave of financialization in the final period under consideration, in a more concrete form, as is evidenced in the last column of table 4. 
Table 4. Evidence for Financialization

\begin{tabular}{|c|c|c|c|c|}
\hline & 1st Period & 2nd Period & 3rd Period & 4th Period \\
\hline & (1900-33) & (1934-40) & (1945-73) & (1974-2010) \\
\hline $\begin{array}{l}\text { Dominance of } \\
\text { Financial Sector }\end{array}$ & Yes & - & No & Yes \\
\hline $\begin{array}{l}\text { Income share/Size of } \\
\text { the Financial Sector }\end{array}$ & Moderate High & Moderate Low & Moderate Low & High \\
\hline Financial Regulation & No & Yes & Yes & No \\
\hline $\begin{array}{l}\text { Shareholder Value } \\
\text { Orientation }\end{array}$ & Yes & - & No & Yes \\
\hline $\begin{array}{l}\text { Intensity of Financial } \\
\text { Innovation }\end{array}$ & Moderate & Moderate & High & High \\
\hline $\begin{array}{l}\text { Household } \\
\text { Indebtedness }\end{array}$ & Moderate High & Low & Moderate & High \\
\hline Income Inequality & High & Low & Low & High \\
\hline $\begin{array}{l}\text { Commitment to Full } \\
\text { Employment }\end{array}$ & No & Yes & Yes & No \\
\hline $\begin{array}{l}\text { Low Inflation } \\
\text { Targeting }\end{array}$ & - & - & No & Yes \\
\hline $\begin{array}{l}\text { Leverage } \\
\text { Structures/Inclination } \\
\text { to Financial Crises }\end{array}$ & High & Low & Low & High \\
\hline
\end{tabular}

\section{CONCLUDING REMARKS}

This paper explored the process of financialization throughout the last century and provided evidence of its deep roots in the beginning of the 20th century. In order to carry out our analysis, we divided our sample period into four distinct phases: the first period ends with the initiation of New Deal in 1933, the second covers the remainder of the 1930s until the outbreak of WWII, the third is the Golden Age (1945-73), and the fourth refers to the neoliberal phase of capitalism, following the oil crisis of 1973 and the beginning of financial deregulation in the US.

The resemblance in the conditions between the first and the fourth period is remarkable. In spite of institutional and formal differences, the presence of primary indicators of financialization, as discussed in this paper, satisfy our main hypothesis, which is that the first period under consideration indeed constitutes an early form of 
financialization. The second period can be viewed as a transitional phase to definancialization, which occurred in the third period under our consideration.

We have shown that the income share of the financial sector rises considerably in the first and the last period, while being significantly lower in the second and third periods.

Pressure on managers to attain short-term profits, contrary to the firms' long-run growth, was evident both at the beginning of the 20th century and in the modern period. This condition has a severe impact on the financial stability of the economic system, since it reduces fixed capital formation or pushes the leverage ratios upwards, inducing financial fragility.

It seems also that financial innovations, which historically constitute a means for the financial system to avoid regulation and thus a significant feature of financialization, do not work in a vacuum. We showed that the rate of growth of financial patents and innovations grew at a steady pace throughout the 20th century. Of utmost importance, however, is whether the implemented regulatory framework allows financial intermediaries to apply new technologies in order to skirt regulation. In line with Minsky (1986), we strongly argue that the adoption of new technologies in finance ought to be backed by an institutional regulatory framework, and properly addressed by promoting regulation as a dynamic process.

There are also significant discrepancies in terms of economic policy between the four periods under examination. For example, the full employment goal was a key priority for policymakers in the second and the third period. Additionally, the dominance of the productive sector and the strengthening of unions are also key features of the third period of definancialization. In advance, monetary policy conducted under a financialized regime, as is the case in the fourth period, emphasizes in the interests of the financial sector, while neglecting those of the productive sector and the working class. In full contrast, monetary policy in the third period aimed to support fiscal stimulus, and therefore enhanced aggregate demand. 
Lastly, the first and especially the last period of financialization shows tremendous rises in the levels of household credit, while in the second and third periods the levels are moderate. Apart from the purely economic outcomes, such as households ending up indebted and financially fragile, this issue becomes critical when considered as an infringement on the cultural setting of the society, with households being bound to the interests of the financial sector. Further, more vast accumulation of household debt leads to financial booms and busts, such as the ones the US witnessed in 2007. Therefore, the need for regulation is also evident in this domain as well.

This paper shows that financialization is not a modern facet of neoliberal capitalism, but a multidimensional process present throughout the 20th century, whose destabilizing consequesnces can only be moderated by appropriate policies and institutional changes, possibly similar to those implemented during the Golden Age of Capitalism. 


\section{REFERENCES}

Aglietta, M. and R. Breton. 2001. "Financial systems, corporate control and capital accumulation." Economy and Society 30(4): 433-66.

Argitis, G. 2013. "Veblenian and Minskian Financial Markets." European Journal of Economics and Economic Policies: Intervention 10(1): 28-43.

Arrighi, G. 1994. The Long Twentieth Century: Money, Power and the Origins of Our Times. London: Verso.

Baker, M., and J. Wurgler. 2000. "The Equity Share in New Issues and Aggregate Stock Returns.” The Journal of Finance 55(5): 2219-57.

Bernstein, P.L. 1996. Against the Gods: The Remarkable Story of Risk. Chichester: John Wiley.

Bertrand, M., D. Karlan, S. Mullainathan, E. Shafir, and J. Zinman. 2010. "What's Advertising Content Worth? Evidence from a Consumer Credit Marketing Field Experiment." Quarterly Journal of Economics 125(1): 263-306.

Bhaduri, A. 2011. "Financialization in the Light of Keynesian Theory." PSL Quarterly Review 64(256): 7-21.

Bhaduri, A., K. Laski, and M. Riese. 2006. "A Model of Interaction Between the Virtual and the Real Economy." Metroeconomica 57: 412-27.

Boyer, R. 2000. "Is a Finance-led Growth Regime a Viable Alternative to Fordism? A Preliminary Analysis.” Economy and Society 29(1): 111-45.

Calder, L. 1999. Financing the American Dream: A Cultural History of Consumer Credit. Princeton, NJ: Princeton University Press.

Crawford, C. 2011. "The Repeal of the Glass-Steagall Act and the Current Financial Crisis.” Journal of Business \& Economics Research 9(1): 127-34.

Cutler, T. and B. Waine. 2010. "Social insecurity and the retreat from social democracy: occupational welfare in the long boom and financialization." Review of International Political Economy 8(1): 96-117.

Dallery, T. 2008. "Post-Keynesian Theories of the Firm Under Financialization." Review of Radical Political Economics 41(4): 492-515.

De Long, J.B. 1991. “Did J.P. Morgan's Men Add Value? An Economist's Perspective on Financial Capitalism." in P. Temin (ed.), Inside the Business Enterprise: Historical Perspectives on the Use of Information. Chicago: University of Chicago Press. 
Dumenil, G., and D. Levy. 2002. "The Profit Rate: Where and How Much Did it Fall? Did it Recover? (USA 1948-2000)." Review of Radical Political Economy 34: 437-61.

Dumenil, G., and D. Levy. 2011. The Crisis of Neoliberalism. London and Cambridge, MA: Harvard University Press.

Dutt, A.K. 2005. "Conspicuous Consumption, Consumer Debt and Economic Growth.” In M. Setterfield (ed.), Interactions in Analytical Political Economy. Theory, Policy and Applications. New York: M.E. Sharpe.

Dymski, G. 1991. "From Schumpeterian Credit Flows to Minskian Fragility: The Transformation of the US Banking System, 1927-1990.” Mimeo. Department of Economics, University of Southern California.

Eichengreen, B., and P. Temin. 1997. "The Gold Standard and the Great Depression." National Bureau of Economic Research, Working Paper No. 6060. Cambridge, MA: NBER.

Epstein, G.A. 2001. "Financialization, Rentier Interests, and Central Bank Policy." Paper prepared for PERI Conference on "Financialization of the World Economy," December 7-8, University of Massachusetts, Amherst.

Epstein, G.A. 2005. Financialization and the world economy. Northampton, MA: Edward Elgar.

Epstein, G.A., and A. Jayadev. 2005. "The Rise of Rentier Incomes in OECD Countries: Financialization, Central Bank Policy and Labor Solidarity." in G.A. Epstein (ed.), Financialization and the World Economy. Northampton, MA: Edward Elgar.

Ferretti, F. 2008. "A Historical Primer on Consumer Credit Reporting Systems: A Lesson for EU Policy Makers?" International Journal of Communication Law and Policy 12: 92-119.

Froud, J., S. Johal, A. Leaver, and K. Williams. 2006. Finanicalization and Strategy: Narrative and Numbers. London and New York: Routledge.

Godley, W., and M. Lavoie. 2007. Monetary Economics: An Integrated Approach to Credit, Money, Income, Production and Wealth. New York: Palgrave MacMillan.

Graeber, D. 2011. Debt: the first 5000 years. London: Melville Press.

Greenwood, R., and D. Scharfstein. 2013. "The Growth of Finance." Journal of Economic Perspectives 27(2): 3-28.

Guseva, A., and A. Rona-Tas. 2001. "Uncertainty, risk, and trust: Russian and American credit card markets compared." American Sociological Review 66(5): 623-646. 
Hein, E. 2008. "Financialization in a Comparative Static, Stock-Flow Consistent PostKaleckian Distribution and Growth Model." IMK Macroeconomic Policy Institute, Working Paper, No 2008-21. Düsseldorf: Hans Böckler Foundation.

Hein, E. 2009. “A (Post-)Keynesian Perspective on Financialization.” IMK Macroeconomic Policy Institute, Studies, No 2009-1. Düsseldorf: Hans Böckler Foundation.

Hein, E., and T. van Treeck. 2008. "Finanicalization in Post-Keynesian Models of Distribution and Growth-A Systematic Review." IMK Macroeocnomic Policy Institute, Working Paper No 2008-10. Düsseldorf: Hans Böckler Foundation.

Hein, E., and M. Mundt. 2013. "Financialization, the Financial and Economic Crisis, and the Requirements and Potentials for Wage-led Recovery." In M. Lavoie and E. Stockhammer (eds.), Wage-led Growth Palgrave Macmillan UK.

Hilferding, R. [1910] 1981. Finance Capital: A Study of the Latest Phase of Capitalist Development. London and Boston: Routledge and Kegan Paul.

Jovanovic, B., and P.L. Rousseau. 2005. "General Purpose Technologies.” Handbook of Economic Growth 1: 1181-1224.

Kent, C., C. Ossolinski, and L. Willard. 2007. "Household Indebtedness: Sustainability and Risk." Paper Presented at the Reserve Bank of Australia "Financial System: Structure and Resilience" Conference, August.

Keynes, J.M. 1936. The General Theory of Employment, Interest and Money. London and New York: Palgrave McMillan.

King, R.G., and R. Levine. 1993. "Finance and Growth: Schumpeter Might Be Right." Quarterly Journal of Economics 108(3): 717-37.

Komai, J., and G. Richardson 2011. "A Brief History of Regulations Regarding Financial Markets in the United States: 1789 to 2009." National Bureau of Economic Research, Working Paper No. 17443. Cambridge, MA: NBER.

Krippner, G. 2005. "The Financialization of the American Economy." Socioeconomic Review 3(2): 173-208.

Lavoie, M. 1995. "The Kaleckian Model of Growth and Distribution and Its NeoRicardian and Neo-Marxian Critiques." Cambridge Journal of Economics 19(6): 789-818.

Langley, P. 2008. "Financialization and the Consumer Credit Boom." Competition Change 12(2): 133-47.

Lazonick, W., and M. O’Sullivan. 2000. "Maximizing Shareholder Value: A New Ideology for Corporate Governance." Economy and Society 29(1): 13-35. 
Lenin, V.I. [1916] 1988. Imperialism, the Higher Stage of Capitalism: A Popular Outline. New York: International Publishers.

Leyshon, A., and N. Thrift. 1999. "Lists Come Alive: Electronic Systems of Knowledge and the Rise of Credit Scoring in Retail Banking." Economy and Society 28(3): 434-66.

Marglin, S.A., and J. Schor. 1990. The Golden Age of Capitalism. Reinterpreting the Postwar Experience. Oxford: Clarendon Press.

Marron, D. 2007. "Lending by Numbers: Credit Scoring and the Constitution of Risk within American Consumer Credit." Economy and Society 36(1): 103-33.

Mehra, R., F. Piguillem, and E.C. Prescott. 2011. "Costly Financial Intermediation in Neoclassical Growth Theory." Quantitative Economics 2(1): 1-36.

Merton, R.C., and A.F. Perold. 1997. "A Model of Contract Guarantees for CreditSensitive, Opaque Financial Intermediaries.” European Finance Review 1: 1-13.

Minsky, H.P. 1986. Stabilizing an Unstable Economy. New Haven and London: Yale University Press.

Minsky, H.P. 1990. "Schumpeter: Finance and Evolution.” In A. Heertje and M. Perlman (eds.), Evolving Technology and Market Structure: Studies in Schumpeterian Economics. Ann Arbor: The University of Michigan Press.

Montgomerie, J. 2006. "The Financialization of the American Credit Card Industry." Competition and Change 10(3): 301-19.

Orhangazi, O. 2008. Financialization and the US Economy. Cheltenham, UK and Northampton, MA: Edward Elgar.

Orlean, A. 1999. Le pouvoir de la Finance. Paris: Odile Jacob.

Palley, T.I. 1994. "Debt, Aggregate Demand, and the Business Cycle: An Analysis in the Spirit of Kaldor and Minsky." Journal of Post Keynesian Economics 16: 37190 .

Palley, T.I. 1999. Plenty of Nothing: The Downsizing of the American Dream and the Case for Structural Keynesianism. Princeton, NJ: Princeton University Press.

Palley, T.I. 2007. "Financialization: What It Is and Why It Matters." Levy Economics Institute, Working Paper No. 525. Annandale-on-Hudson, NY: Levy Economics Institute of Bard College.

Papadimitriou, D. 2008. "Promoting Equality Through an Employment of Last Resort Policy.” Levy Economics Institute, Working Paper No. 545. Annandale-onHudson, NY: Levy Economics Institute of Bard College. 
Peach, W.N. 1941. The Security Affiliates of National Banks. Baltimore: Johns Hopkins Press.

Philippon, T. 2015. "Has the US Finance Industry Become Less Efficient? On the Theory and Measurement of Financial Intermediation." American Economic Review 105(4): 1408-38.

Phillips, K.P. 1996. Boiling Point: Democrats, Republicans, and the Decline of Middle-Class Prosperity. New York: Random House.

Pineault, E. 2001. "Finance Capital and the Institutional Foundations of Capitalist Finance: Theoretical Elements from Marx to Minsky." Unpublished Paper. Ecole des Hautes Etudes en Sciences Sociales, Paris.

Roberts, J., P. Sanderson, R. Barker, and J. Hendry. 2006. "In the Mirror of the Market: The Disciplinary Effects of Company/Fund Manager Meetings." Accounting, Organization and Society 31(3): 277-94.

Rousseau, P.L., and P. Wachtel. 2000. "Equity Markets and Growth: Cross-country Evidence on Timing and Outcomes: 1980-1995." Journal of Banking and Finance 24: $1933-57$.

Sawyer, M. 2013-14. "What Is Financialization?" International Journal of Political Economy 42(4): 5-18.

Schularick, M. and A.M. Taylor. 2012. "Credit booms gone bust: monetary policy, leverage cycles, and financial crises, 1870-2008." The American Economic Review 102(2):1029-61.

Sotiropoulos, D. 2012. "Hilferding on Derivatives." The European Journal of the History of Economic Thought 22(1): 77-96.

Stockhammer, E. 2004. "Financialization and the Slowdown of Accumulation." Cambridge Journal of Economics 28(5): 719-41.

Stockhammer, E. 2005-06. "Shareholder Value Orientation and the Investment Profit Puzzle." Journal of Post Keynesian Economics 28(2): 193-216.

Van Treeck, T. 2008a. "A Synthetic, Stock-Flow Consistent Macroeconomic Model of "Financialization." Cambridge Journal of Economics 33(3): 467-93.

Van Treeck, T. 2008b. "Reconsidering the Investment-Profit Nexus in Finance-led Economies: An ARDL-Based Approach.” Metroeconomica 59(3): 371-404.

Vercelli, A. 2013-14. "Financialization in a Long-Run Perspective." International Journal of Political Economy 42(4): 19-46.

U.S. Senate. 1931. Hearing on S.R. 71. Before the Committee on Banking and Currency. 71st Congress, 2nd Session.. 
Veblen, T. 1904. The Theory of Business Enterprise. New York: Scriber's Sons.

White, E.N. 1986. "Before the Glass-Steagall Act: An Analysis of the Investment Banking Activities of National Banks." Explorations in Economic History 23(1): $33-55$. 